\title{
PACIENTŲ ŠEIMOS NARIŲ PASITENKINIMO GYDYMU IR SLAUGOS KOKYBE BEI SPRENDIMŲ PRIE்MIMU LIETUVOS SVEIKATOS MOKSLŲ UNIVERSITETO KAUNO KLINIKU NEUROCHIRURGIJOS INTENSYVIOS TERAPIJOS SKYRIUJE VERTINIMAS
}

\author{
Monika Sasnauskaite் ${ }^{1}$, Vytautas Jašinskas ${ }^{2}$, Tomas Tamošuitis ${ }^{3}$, Ingrida Urboniené $\dot{e}^{3}$, \\ Neringa Balčiūniené $\dot{~}^{3}$ \\ ${ }^{1}$ Lietuvos sveikatos mokslu universiteto Kauno klinikos, Anesteziologijos klinika, \\ ${ }^{2}$ Lietuvos sveikatos mokslu universitetas, \\ ${ }^{3}$ Lietuvos sveikatos mokslu universiteto Kauno kliniku Neurochirurgijos klinika, \\ Intensyviosios terapijos skyrius
}

Raktažodžiai: neurochirurgijos intensyvios terapijos skyrius, šeimos nariai, gydymas ir slauga, FS- ICU 24.

\begin{abstract}
Santrauka
Intensyvios terapijos skyriuose gydomi pacientai dažnai negali išreikšti savo požiūrio ir nuomonès apie jiems taikomą gydymą ir slaugą dẻl kritiškai sunkios sveikatos būklès. Tokiais atvejais artimieji tampa jų atstovais, veikiančiais pacientų vardu. Artimieji, vertindami personalo darbą, gydymo sprendimų prièmimą, taip pat tampa ligoniui taikomo gydymo ir slaugos kokybès vertintojais. Dèl šios priežasties medicinos personalo veikla turi užtikrinti ne tik tinkamą intesnsyvios terapijos skyriuje gydomo paciento priežiūrą, bet ir atsižvelgti ị pacientų artimųjų nuomonę bei lūkesčius.

Tyrimo rezultatai parodè, kad pacientų artimieji pasitenkinimą gydymo ir slaugos kokybe bei sprendimų prièmimu vertina gerai.
\end{abstract}

\section{Ivadas}

Gydymo ịstaigų veikla yra tiesiogiai susijusi su asmens sveikatos priežiūra, todèl kasdienèje praktikoje jų veiklos kokybei keliami aukšti reikalavimai. Pacientai, gydomi intensyviosios terapijos skyriuose (ITS), dèl itin sunkios sveikatos būklės patys dažniausiai negali priimti sprendimų, todèl šeimos nariai tampa jų atstovais [1]. Grižtamasis ryšys iš pacientų ir jų artimos aplinkos, ypač šeimos narių, laikomas vienu iš gydymo ịstaigų veiklos tobulinimo krypti identifikuojančiu įrankiu, todèl tokiose šalyse kaip Danija,
Didžioji Britanija bei JAV atliekami nuolatiniai stebejjimai, kurie padeda ịvertinti pacientų ir jų šeimos narių pasitenkinimą gydymo ịstaigos veikla. Kitose šalyse toks vertinimas nèra reguliarus, atliekami pavieniai nacionaliniai arba atskiru gydymo ir sveikatos priežiūros ịstaigų lygmeniu [2].

Pacientų artimujų požiūriui ị ITS veiklą įtakos turi ne tik taikomas gydymas, bet ir gydytojų bendradarbiavimas su paciento šeima bei informacijos apie paciento būklę prieinamumas, suprantamumas. Atliktuose tyrimuose pastebèta, kad ITS stacionarizuotų pacientų būklès sunkumas dažnai kelia nerimą, baimę ir nežinomybę pacientų artimiesiems, todèl labai svarbus tampa gydytojų atvirumas bei gebejjimas bendrauti, atsakyti ị šeimos nariams iškylančius klausimus [3]. Teigiama, jog išsamus informacijos suteikimas apie pacientui taikomą gydymą ir slaugą ITS gali sumažinti nerimo lygį bei padidinti šeimos narių pasitenkinimą sveikatos priežiūros paslaugomis [1]. Pacientų šeimos narių pasitenkinimą taip pat formuoja medicinos personalo kompetencija, paciento priežiūros kokybė, pateikiamos informacijos nuoseklumas, artimujų įtraukimas ị sprendimų prièmimo procesą [4]. Šeimos nariai nèra tik gydymo ịstaigos lankytojai, jie taip pat turi savo nuomonę ir lūkesčius, todèl vertinant paciento šeimos poreikius ir pasitenkinimą gydymu informacijos prieinamumas ir sprendimų prièmimas turètų būti neatsiejama kokybès vertinimo dalis [5].

Atlikto tyrimo tikslas - išsiaiškinti šeimos narių pasitenkinimą gydymu ir slaugos kokybe bei sprendimų priëmimu, rūpinantis artimuoju, gydomu Lietuvos sveikatos mokslų universiteto Kauno klinikų Neurochirurgijos klinikos intensyvios terapijos skyriuje. 


\section{Tyrimo metodika}

Siekiant įvertinti pacientų, gydomų Lietuvos sveikatos mokslų universiteto Kauno klinikų (LSMUL KK) Neurochirurgijos klinikos intensyviosios terapijos skyriuje (NITS) šeimos narių pasitenkinimą gydymo ir slaugos kokybe, pasirinkta standartizuota FS-ICU 24 anketa. Gautas autorių leidimas naudoti anketą šiam tyrimui. Atliktas prospektyvinis tyrimas LSMUL KK NITS 2017 m. birželio - rugsèjo mènesiais. Ittraukimo ị tyrimą kriterijai: tiriamasis turejjo būti paciento šeimos narys, pacientas stacionarizuotas i NITS $\geq 72$ val., šeimos nariai lankẻ pacientą jo stacionarizavimo NITS metu bent du kartus. Tyrimo metu šeimos nariai užpildè anoniminę FS-ICU 24 apklausą, kurią sudaro dvi dalys: pirmojoje vertinamas pacientų artimujų pasitenkinimas gydymu ir slauga, antrojoje - šeimos narių pasitenkinimas sprendimų, susijusių su jų artimųų gydymu ir slauga, priėmimu. Pacientų pasitenkinimą nurodantys atsakymai pateikiami Likerto (Likert) skalès principu - nuo blogai iki puiku. Statistinè analize atlikta naudojant „SPSS“ ir "Excel” programas. Taikyti chi kvadrato kriterijus, Kruskalio Voliso (Kruskall-Wallis) testai, skaičiuotas kiekybinių duomenu vidurkis \pm standartinis nuokrypis, bendras pasitenkinimas apskaičiuotas Likerto skalès balų (0-5) procentine išraiška. Skirtumai tarp grupių laikomi statistiškai reikšmingais, kai $\mathrm{p}<0,05$.

\section{Tyrimo rezultatai}

Tiriamuoju laikotarpiu 105 šeimos nariai atitiko ịtraukimo kriterijus, tačiau anketos atsakomumas buvo $77,1 \%$. Iš viso atliktame tyrime dalyvavo 81 respondentas - $59(72,8 \%)$ moterys ir $22(27,2 \%)$ vyrai, kurių amžiaus vidurkis buvo $46,6 \pm 14,1$ metų. Didžiają dalị tiriamujjų sudare pacientų vaikai $35(43,8 \%)$ ir $18(22,5 \%)$ - sutuoktiniai. $44,5 \%$ pacientų gyveno kartu su savo artimaisiais. Šeimos nariai, kurie prieš stacionarizavimą gyveno atskirai ir lankè artimajji dažniau, jiems skirtą personalo emocinę paramą ir rūpestingumą vertino palankiau $(\mathrm{p}=0,04)$. Nustatyta, kad tiriamujuc lytis, amžius, giminystès ryšys, gyvenamoji vieta neturejo įtakos jų pasitenkinimui gydymu ir slauga bei sprendimų prièmimu $(p>0,05)$. Nustatytas bendras šeimos narių pasitenkinimas gydymu ir slauga $82,1 \pm 13,8 \%$ (geras) ir pasitenkinimas sprendimų prièmimu $81,0 \pm 16,3 \%$ (geras). Remiantis tyrimo rezultatais, 47,2\% pacientų artimujų jautèsi turintys užtektinai įtakos priimant sprendimus, tačiau 9,7\% tyrimo dalyvių jautèsi visiškai jos neturintys.

\section{Tyrimo rezultatų aptarimas}

Gydant sunkios ir kritinès būklès pacientus, svarbu visą dèmesị sutelkti ne tik ị tiesiogini pacientų gydymo procesą, tačiau nepamiršti paciento šeimos narių, nuoširdaus bendravimo su jais, lūkesčių išaiškinimo. İrodyta, jog efektyvus ITS personalo bendradarbiavimas su artimaisiais didina jų pasitenkinimo lygị taikomu gydymu, pasitikejjimą gydytojais, suteikia geresnę psichologinę atmosferą, todẻl svarbu kiek įmanoma daugiau ịtraukti šeimos narius ị gydymo procesą [6].

Mūsų atlikto tyrimo duomenimis, artimieji pasitenkinimą pacientų priežiūra ir galimybę dalyvauti priimant sprendimus vertino gerai. Graikijoje atlikto tyrimo rezultatai panašūs, jame didžioji dalis tiriamujų ( 81 \%) pasitenkinimą ligonių priežiūra vertino labai gerai ar puikiai, teigiamai vertino ir jiems suteiktą vaidmeni priimant sprendimus [7]. Taip pat mūsų tyrimo duomenys panašūs ir su 2015 m. Jungtinèje Karalysteje atlikto tyrimo rezultatais: nustatytas aukštas pasitenkinimo lygis: ITS veikla $-80 \%$, slauga $-83 \%$, o pasitenkinimas sprendimų prièmimu $-70 \%$ [8]. Tuo tarpu K.Clark ir kt. atliktame tyrime rezultatai buvo prastesni: artimieji pasitenkinimą ITS personalo veikla prižiūrint pacientus vertino $72,2 \%$, o galimybę dalyvauti priimant sprendimus - 72,0\% [9]. Mūsų gauti didžiai vertinami šeimos narių pasitenkinimo rezultatai galejjo būti sąlygoti gana mažos tiriamujų imties. Taip pat ịtakos galejo turèti ir tai, kad artimieji anoniminę FS-ICU 24 anketą pildè paciento stacionarizavimo ITS metu - palankesni vertinimai galèjo būti pasirinkti sąmoningai, tikintis, jog tai turès ịtakos tolimesniam gydymui, nors anketoje nurodyta, jog tiriamujų atsakymai anonimiški ir konfidencialūs, o jų rezultatai nelems tolimesnių šeimos nario gydymo taktikos pokyčių ar priežiūros kokybès. Nors mūsų atliktame tyrime nenagrinejjome pasitenkinimo ryšio su paciento būklès sunkumu, tačiau anksčiau atliktuose tyrimuose nustatytas toks ryšys - pasitenkinimas gydymu ir priežiūra geriau ịvertintas tų šeimos narių, kurių artimieji buvo sunkesnès buklės [5]. G.Frivold ir kt. tyrime šeimos nariai, kurių artimieji mire ITS, buvo labiau patenkinti ịtraukimu ị gydymo sprendimų prièmimą nei šeimos nariai, kurių artimieji išgyveno [10]. $2015 \mathrm{~m}$. S.Wright studijoje nustatytas bendro pasitenkinimo ITS veikla sąsajos su paciento gydymo trukme, kas taip pat dažnai rodo paciento sveikatos būklès sunkumą [8].

Mūsų atliktame tyrime nestebèta statistiškai reikšmingo skirtumo tarp artimujų lyties ir pasitenkimo gydymu ir slauga, tačiau 2018 m. G.Frivold ir kt. atliktame tyrime nustatyta, kad moterims dažniau reikia suteikti informaciją apie sergantị šeimos narị, taip pat moterys, kurios rūpinasi sergančiuoju, patiria didesnị stresą, nerimą, psichologinị išsekimą ar depresiją nei vyrai [10]. Autorius tai grindžia tuo, kad moterys dažnai yra jautresnès nei vyrai ir labiau reaguoja ì gydymo ir slaugos pasikeitimus, būklès nestabilumą [10]. S.Wright ir kt. atliktame tyrime artimujų vertinimui ịtakos turejjo jų amžius, ryšys su pacientu bei jo lankymo dažnunas [8]. Mūsų tyrime bendras artimujų pasitenkinimas paciento gydymu ir priežiūra bei galimybe priimti sprendimus nepriklausè ne tik nuo tiriamujų lyties, bet ir nuo tiriamojo šeimos 
nario amžiaus, giminystès ryšio, gyvenamosios vietos. Nustatytas vienintelis statistiškai reikšmingas rezultatas - šeimos nariai, prieš paciento stacionarizavimą i NITS gyvenę atskirai ir lankę artimajị dažniau, jiems personalo suteiktą emocinę paramą ir rūpestingumą vertino palankiau $(p=0,04)$. Nors mūsų atliktame tyrime vertintas tik pacientų šeimos narių pasitenkinimas, svarbu paminèti, jog užsieny atliktų tyrimų rezultatai parodè, jog ITS pacientų šeimos ir pačių pasveikusiujų pasitenkinimas ITS veikla nèra toks pat - pasveikę pacientai labiausiai vertina jiems taikyto gydymo kokybę, tuo tarpu artimujų pasitenkinimui labiausiai itakos turi gydytoju ir slaugytojų asmeninès savybės bei kompetencija [11].

Šiame tyrime bendras pasitenkinimas sprendimų prièmimu vertintas $81,0 \pm 16,3 \%$, pusè $(55,3 \%)$ visų tiriamųu jautėsi ịtraukti ị sprendimų prièmimą. Nors $47,2 \%$ jautèsi turintys užtektinai įtakos sprendžiant gydymo ir slaugos klausimus, ketvirtis tiriamujjų $(25,0 \%)$ jautėsi nei turintys, nei neturintys įtakos. Tuo tarpu M.Zouka ir bendraautorių studijoje net $73 \%$ tirtujų jautėsi nei turintys, nei neturintys itakos priimant su gydymu ir slauga susijusius sprendimus [7]. Atlikus tyrimą Šveicarijos medicinos ịstaigų ITS, nustatyta, kad norint labiau įtraukti pacientų artimuosius ị gydymo ir slaugos sprendimų prièmimą, reikalingas atviras ITS personalo bendradarbiavimas su šeimomis. Jų gautuose rezultatuose bendras pasitenkinimas vertintas $78 \pm 14 \%$, pasitenkinimas priežiūra $79 \pm 14 \%$, pasitenkinimas sprendimų prièmimu $-77 \pm 15$ proc [5]. A.Slettebo ir kt. atliktame tyrime nustatyta, kad šeimos nariai buvo patenkinti pacientu gydymu ir rūpinimusi, tačiau mažiau patenkinti galimybe priimti sprendimus bei ITS darbuotojų komunikacija su artimaisiais [10]. G.Frivold ir bendraautorių tyrime taip pat teigiama, jog ITS pacientų artimujų pasitenkinimas ligonio priežiūra ir slauga yra aukštesnis, negu pasitenkinimas galimybe priimti sprendimus dèl taikomo gydymo [10].

Tinkamas bendradarbiavimas tarp personalo skatina artimujų pasitikejjimą pacientų priežiūros kokybe ir tinkamų gydymo veiksmų užtikrinimu [12], o bet koks komunikacijos tarp ITS personalo ar darbo sutrikdymas, dažnai pastebimas pacientų artimujų bei gali formuoti neigiamą požiūrị ị darbą ITS [13]. Mūsų atliktame tyrime mažiau nei pusė $(46,3 \%)$ apklaustujų personalo darbo koordinavimą vertino puikiai. Siekiant gerinti pacientų artimųjų požiūrị i ̣ personalo darbą ITS, užsienio šalyse yra vedamos specialios mokymų programos, skirtos bendravimo su artimaisias igūdžiams tobulinti [14]. Jeigu tokios programos būtų plačiai vykdomos ir mūsų valstybejje, tikètina, kad artimieji galètų objektyviau vertinti darbą ITS. Svarbu paminèti, jog šeimos nariai tikisi kokybiško bendradarbiavimo tarp personalo, kuri sudaro ne tik gydytojai, tačiau ir slaugytojai bei jų padejejejai [15], todèl svarbu, kad sklandžiai dirbtų visos personalo grandys. Užsienio autorių atlikti tyrimai įrodo, kad pacientų artimieji labiausiai vertina slaugytojo atsakomybę, laiką skiriamą rūpintis sunkios būklès pacientu [11]. L.Stayt teigimu, pacientų artimieji iš slaugytojų tikisi ne tik malonaus bendravimo, bet ir moralinès paramos, jų atskirties nuo gydymo proceso panaikinimo [16]. Mūsų atliktame tyrime bendravimą su slaugytojomis puikiai vertino $43,2 \%$, o slaugytojų igūdžius puikiai vertino $-42,0 \%$ apklaustujų. Kasdienèje praktikoje slaugytojams tenka sunki užduotis balansuoti tarp pacientų šeimos narių lūkesčiu ir asmeninių vertybių, savo atliekamo darbo pareigybių bei slaugytojo darbo etikos [16]. Tuo tarpu gydytojai yra tiesiogiai atsakingi už ITS gulinčių pacientu gydymą - jie turi užtikrinti visapusį paciento saugumą ir komfortą [5]. Mūsų atliktame tyrime 44,4\% tiriamujjų gydytojų igūdžius ir kompetenciją rūpintis jų šeimos nariais ivvertino puikiai. Rezultatai prastesni lyginant su 2001 m. D.Heyland ir bendraautorių studijos rezultatais - net 63\% artimujų gydytojų rūpestị ir kompetenciją vertino puikiai [17]. Vis dèlto gana didelis rezultatų skirtumas galèjo būti dèl beveik dvigubai mažesnès pastarojo tyrimo imties. Taip pat mūsų kasdienèje praktikoje ITS gydytojai dèl vienam specialistui tenkančio didelio pacientų skaičiaus negali skirti jų artimiesiems pakankamai laiko. Lietuvoje gydytojas ITS vidutiniškai rūpinasi 6-9 pacientais. $2017 \mathrm{~m}$. JAV atlikto tyrimo duomenimis, optimalus ITS gydytojui tenkantis pacientų skaičius yra 1-5, o jei gydytojo prižiūrimų pacientu skaičius $\geq 6$, jo tikimybè patirti perdegimo sindromą dideja trigubai - 33\% [18]. Perdegimo sindromas toliau gali prisidèti prie prastesnès bendravimo kokybès ir sąlygoti prastesnius šeimos narių vertinimus. Atliktuose tyrimuose taip pat buvo pastebèta, kad slaugytojai yra dažniau linkę palaikyti ryšius su pacientų artimaisiais, negu gydytojai [19]. Tai taip pat gali būti aiškinama slaugytojui tenkančiu mažesniu pacientų skaičiumi. Ateityje, esant galimybèms, būtų naudinga didinti dirbančių ITS gydytojų skaičių, tobulinti jų bendravimo su artimaisiais igūdžius, skatinti gydytojus pokalbio metu isitikinti artimiesiems suteiktos informacijos suprantamumu. Visa tai leistu pasiekti geresnès šeimos nariu ir ITS gydytojų bendradarbiavimo kokybès.

\section{Išvados}

Nustatyta, kad pacientų, stacionarizuotų LSMUL KK NITS, artimųų pasitenkinimas medicinine priežiūra ir slauga vertintas $-82,1 \pm 13,8 \%$, o galimybe priimti sprendimus $-81,0 \pm 16,3 \%$. Atlikto tyrimo rezultatai panašūs su užsienio autorių rezultatais. Tyrime nenustatyta statistiškai reikšmingo skirtumo tarp bendro pasitenkinimo medicinine priežiūra ir slauga bei sprendimų prièmimu priklausomai nuo tiriamojo lyties, amžiaus, ry- 
šio su pacientu, paciento lankymo iki stacionarizavimo.

\section{Literatūra}

1. Lai VKW, Lee A, Leung P. et al. Patient and family satisfaction levels in the intensive care unit after elective cardiac surgery: study protocol for a randomised controlled trial of a preoperative patient education intervention. BMJ Open 2016;6:e11341. https://doi.org/10.1136/bmjopen-2016-011341

2. Goštautaitė B. Pacientų ir sveikatos priețiūros paslaugų teikèju pasitenkinimo teikiamų paslaugų kokybe bei prieinamumu analizè (I dalis). Europos tyrimai, 2011.

3. Falk AC, Wallin AM. Quality of patient care in critical care units: in relation to nurse/patient ratio. Intensive Care Medicine Experimental 2015; 3(1):479.

https://doi.org/10.1186/2197-425X-3-S1-A479

4. Sarode V, Sage D, Reeves J. Intensive care patient and family satisfaction. International Journal of Health Care Assurance 2015; 28(1):75-81.

https://doi.org/10.1108/IJHCQA-02-2014-0018

5. Stricker K, Mohr U, Rothen HU. Family satisfaction in the intensive care unit: what makes the difference? Intensive Care Medicine 2009;35(12):2051-9.

https://doi.org/10.1007/s00134-009-1611-4

6. Wood GJ, Chaitin E, Arnold RM. Communication in the ICU: holding a family meeting. 2019. UpTo Date.

7. Zouka M, Myrou A, Soultati I. et al. Family satisfaction in the ICU: a 6-month experience. Critical Care 2014; 18(Suppl 1):P27. https://doi.org/10.1186/cc13217

8. Wright SE, Harvey SE, Walsley E. et al. Family satisfaction with critical care in the United Kingdom. Intensive Care Medicine Experimental 2015; 3(1):22.

https://doi.org/10.1186/2197-425X-3-S1-A22

9. Clark K, Milner KA, Beck M. et al. Measuring family satisfaction with care delivered in the intensive care unit. Critical Care Nurse 2016; 36(6):8-14. https://doi.org/10.4037/ccn2016276

10. Frivold G, Slettebo A, Heyland. et al. Family members' satisfaction with care and decision-making in intensive care units and post-stay follow-up needs-a cross-sectional survey study. Nursing Open 2017; 5(1):6-14. https://doi.org/10.1002/nop2.97

11. Mukhopadhyay A, Song G, Sim PZ. et al. Satisfaction domains differ between the patient and their family in adult intensive care units. BioMed Research International 2016; ID 9025643. https://doi.org/10.1155/2016/9025643

12. Rensen A, Mol N, Menheere I. Quality of care in the intensive care unit from the perspective of patient's relatives: development and psychometric evaluation of the consumer quality index ,R-ICU. BMC Health Research 2017;17(1)77.

https://doi.org/10.1186/s12913-016-1975-4

13. Schwarzkopf D, Behrend S, Skupin H. et al. Family satisfaction in the intensive care unit: a quantitative and qualitative analysis. Intensive Care Med 2013; 39(6):1071-9.

https://doi.org/10.1007/s00134-013-2862-7
14. Cicekci F, Duran N, Ayhan B. et al. The communication between patient relatives and physicians in intensive care units. BMC Anesthesiology 2017; 17(1):97. https://doi.org/10.1186/s12871-017-0388-1

15. Henrich NMJ, Dodek P, Heyland D. et al. Qualitative analysis of an intensive care unit family satisfaction survey. Critical Care Medicine 2011; 39(5):1000-5.

https://doi.org/10.1097/CCM.0b013e31820a92fb

16. Stayt LC. Nurses' experiences of caring for families with relatives in intensive care units. Journal of Advanced Nursing 2007; 57(6):623-30.

https://doi.org/10.1111/j.1365-2648.2006.04143.x

17. Heyland DK, Tranmer JE. Measuring family satisfaction with care in the intensive care unit: the development of a questionnaire and preliminary results. Journal of Critical Care 2001; 16(4):142-149.

https://doi.org/10.1053/jcrc.2001.30163

18. Bhatt M, Lizano D, Carlese A. et al. Severe burnout is common among critical care physician assistants. Critical Care Medicine 2017; 45(11):1900-06.

https://doi.org/10.1097/CCM.0000000000002689

19. Basinska K, Owczuk R. The relationship between family members of intensive therapy unit patients and medical staff. Anestezjologia Intensywna Terapia 2011; 43(2):89-9.

\section{EVALUATION OF PATIENTS' FAMILY MEMBERS' SATISFACTION WITH THE QUALITY OF TREATMENT, NURSING AND DECISION-MAKING AT THE NEUROSURGERY INTENSIVE CARE UNIT OF THE HOSPITAL OF LITHUANIAN UNIVERSITY OF HEALTH SCIENCES \\ M.Sasnauskaitė, V.Jašinskas, T.Tamošuitis, I.Urbonienė, N.Balčiūnienẻ}

Keywords: neurosurgery intensive care unit, family members, treatment and nursing, FS- ICU 24.

Summary

Patients who are treated at the intensive care unit (ICU) are often unable to express their opinion about the treatment and nursing which are given to them because of their critical illness. Relatives and family members of these patients become representatives of them, acting on behalf of the patients. They also become the assessors of treatment and nursing which the patient receives and also of the quality of work, performed by ICU personnel. For this reason, the activities of the medical personnel must ensure not only the proper care of the patient at ICU, but also consider the views and expectations of the patients" relatives.

The aim of the study was to evaluate the satisfaction of the patients' family members' with the quality of treatment and nursing as well as the decision-making at the Hospital of Lithuanian University of Health Sciences Kaunas Clinics, Neurosurgery Intensive Care Unit.

The results of the study revealed that the family members were satisfied with the quality of treatment, nursing and decision-making.

Correspondence: sasnauskaite.monika@gmail.com

Gauta 2019-05-18 